\title{
RENAL EXCRETION OF POTASSIUM IN NORMAL AND SODIUM DEPLETED DOGS ${ }^{1}$
}

\author{
By HELEN M. ANDERSON aNd JOHN H. LARAGH with THE TECHNical assistance \\ of CLARA W. HALL, SALLY MOORE, AND JOSEPH HARTOG
}

(From the Department of Medicine, College of Physicians and Surgeons, Columbia University, and The Presbyterian Hospital in the City of New York, N.Y.)

(Submitted for publication July 26, 1957 ; accepted October 31, 1957)

There is considerable evidence indicating that the renal loss of potassium is reduced in both man and animals following the establishment of a sodium retaining state. Seldin, Welt, and Cort (1) and Relman and Schwartz (2) have demonstrated that a low sodium diet limits the excretion of potassium in patients and in rats receiving either desoxycorticosterone (DCA) or hydrocortisone. In addition, Milne, Hughes Jones, and Evans (3), studying normal individuals on a low potassium diet, found that the renal conservation of this ion was more efficient when the sodium intake was also reduced. Dogs forming ascites after thoracic caval constriction have been shown to retain nearly all ingested sodium, and frequently to exhibit hyperkalemia. When these animals were given DCA, the expected kaliuresis did not occur (4). It has been postulated that the failure of kaliuresis in these and other similar circumstances is secondary to a low sodium content of distal tubular urine. Such a reduction in sodium content might limit the amount of sodium available for exchange with potassium ions in the distal tubule (5), the presumed site of potassium secretion.

However, balance studies in patients with heart failure or cirrhosis and in dogs depleted of sodium by peritoneal dialysis have failed to demonstrate net potassium retention at a time when the urinary sodium excretion was very low $(6,7)$. Furthermore, when potassium salts were administered to these subjects, the potassium balance was not altered although significant hyperkalemia was observed. The elevation of plasma potassium was considerably greater than any change seen in similarly treated normal individuals. In these studies

1 This work was supported in part by a grant from the United States Public Health Service, National Heart Institute (USPHS H-1275), and the Fleitas Foundation Fund. the hyperkalemia could not be definitely related to diminished renal excretion of potassium.

The present experiments were undertaken in an attempt to examine the capacity of the sodium depleted dog to excrete potassium during acute loading experiments and to test the hypothesis that the hyperkalemia observed in sodium depleted states might be the result of failure of the renal secretory mechanism.

\section{METHODS}

Clearance studies were carried out in nine trained, unanesthetized female mongrel dogs, weighing 12 to 21 kilograms. Each dog was studied before and again after sodium depletion. The first study was done after the dogs had been maintained on a stock diet containing at least $100 \mathrm{mEq}$. of sodium per day and a supplement of $150 \mathrm{mEq}$. of potassium. Sodium chloride depletion of the animals was accomplished by peritoneal dialysis according to the method of Darrow and Yannet (8). The dogs were then maintained on a synthetic diet containing no sodium and 150 millimoles of potassium chloride per day. The animals were restudied two to seven days after the dialysis.

Renal clearances were performed using the clearance of exogenous creatinine as a measure of the glomerular filtration rate. Following a priming dose of creatinine and a half-hour equilibration period, two 20 minute control periods were obtained before either $\mathrm{KCl}$ or $\mathrm{K}_{2} \mathrm{SO}_{4}$ (potassium concentration $150 \mathrm{mEq}$. per L.) in 1 per cent creatinine solution was infused at a constant rate. Urine was collected from an indwelling catheter, and each clearance period was terminated by washing the bladder once with $15 \mathrm{ml}$. of distilled water. Venous blood samples were collected in heparinized syringes at the midpoint of each period.

Creatinine was measured in sodium tungstate filtrates of plasma and in diluted urine by the alkaline-picrate method. Sodium and potassium in diluted plasma and urine were determined by internal standard flame photometry. Chloride was estimated by a modification of the Volhard titration method. The calculation of the potassium clearance incorporated a ratio of ultrafiltrate concentration to plasma water concentration of 0.95 (Gibbs-Donnan effect). 


\section{RESULTS}

Table I summarizes 18 experiments in nine animals. The first five clearance studies (Dogs $\mathrm{P}, \mathrm{T}, \mathrm{G}, \mathrm{Sp}$ and $\mathrm{C}$ ) were carried out using $\mathrm{KCl}$ as the loading salt. In the remainder, $\mathrm{K}_{2} \mathrm{SO}_{4}$ was employed. The total amount of potassium administered, the potassium excreted and the sodium excreted in each clearance period is recorded. If the two studies in the same animal are compared it can be seen that each dog excreted approximately the same fraction of the administered potassium before and after sodium depletion. The average glomerular filtration rate following sodium depletion in these animals tended to be lower than in the control experiments. Appreciable reduction in plasma sodium was uniformly produced by the dialysis procedure, and urinary excretion of sodium was markedly reduced in all instances. These changes indicate that the amount of sodium in the tubular urine was considerably decreased in the studies done after dialysis. The plasma chloride concentration in the normal animals averaged $108 \mathrm{mEq}$. per L. before $\mathrm{KCl}$ was given. At the end of the infusion a maximum level of $117 \mathrm{mEq}$. per L. was observed. After depletion the average initial chloride concentration was $90 \mathrm{mEq}$. per L., and reached a maximum of 105 $\mathrm{mEq}$. per L. after infusion of chloride salt.

The details of a representative experiment in which $\mathrm{KCl}$ was infused are given in Table II. Large amounts of potassium appeared in the urine both before and after sodium depletion, and the ratios of the clearance of potassium to the clearance of creatinine $\left(\mathrm{C}_{\mathrm{K}} / \mathrm{C}_{\mathrm{Cr}}\right)$ were similar in the two situations. Following sodium depletion only small amounts of this ion were present in the bladder urine, and a marked increase in the ratio urine $[\mathrm{K}]$ to urine $[\mathrm{Na}]$ was apparent.

The results of a typical experiment in which $\mathrm{K}_{2} \mathrm{SO}_{4}$ was given are shown in Table III. Urine potassium content was higher in this control study than in that of Dog $\mathrm{P}$ above, and this increase could not be entirely accounted for in terms of the total dose administered in the two studies ( $c f$. , Table I), but was consistent with the results one might expect when nonreabsorbable $\mathrm{SO}_{4}{ }^{2}$ is em-

TABLE I

Summary of paired clearance studies in nine dogs before and after sodium chloride depletion*

\begin{tabular}{|c|c|c|c|c|c|c|c|c|c|c|c|c|c|c|}
\hline \multirow[b]{3}{*}{ Dog } & \multirow{2}{*}{\multicolumn{2}{|c|}{$\begin{array}{l}\text { Average } \\
\text { creatinine } \\
\text { clearance }\end{array}$}} & \multicolumn{4}{|c|}{ Plasma concentrations } & \multirow{2}{*}{\multicolumn{2}{|c|}{$\begin{array}{c}\text { Total } \\
\text { potassium } \\
\text { infused }\end{array}$}} & \multirow{2}{*}{\multicolumn{2}{|c|}{$\begin{array}{c}\text { Cumulative } \\
\text { potassium } \\
\text { excreted }\end{array}$}} & \multirow{2}{*}{\multicolumn{2}{|c|}{$\begin{array}{c}\text { Potassium } \\
\text { excreted } \\
\text { (\% of potassium } \\
\text { infused) }\end{array}$}} & \multirow{2}{*}{\multicolumn{2}{|c|}{$\begin{array}{l}\text { Cumulative } \\
\text { sodium } \\
\text { excreted }\end{array}$}} \\
\hline & & & \multicolumn{2}{|c|}{ Sodium } & \multicolumn{2}{|c|}{ Potassium } & & & & & & & & \\
\hline & $\overline{B \ddagger}$ & $\bar{A}$ & B & $\mathrm{A}$ & B & A & B & A & B & A & B & A & B & $\bar{A}$ \\
\hline & \multicolumn{2}{|c|}{ ml./min. } & \multicolumn{4}{|c|}{$m E q . / L$. } & \multicolumn{2}{|c|}{$m E q}$. & \multicolumn{2}{|c|}{$m E q$. } & & & \multicolumn{2}{|c|}{$m E q$. } \\
\hline $\mathrm{P} \dagger$ & 67 & 44 & 148 & 132 & $\begin{array}{l}3.4- \\
5.6\end{array}$ & $\begin{array}{l}5.7- \\
9.5\end{array}$ & 93 & 105 & 34.3 & 46.4 & 36.5 & 43.0 & 9.4 & 0.7 \\
\hline $\mathrm{T}$ & 80 & 73 & 144 & 129 & $\begin{array}{l}4.2- \\
7.0\end{array}$ & $\begin{array}{l}5.0- \\
7.6\end{array}$ & 125 & 117 & 45.6 & 51.6 & 30.4 & 43.0 & 12.6 & 1.2 \\
\hline $\mathrm{G} \dagger$ & 61 & 61 & 144 & 125 & $\begin{array}{l}4.3- \\
6.8\end{array}$ & $\begin{array}{l}6.1- \\
8.1\end{array}$ & 84 & 89 & 39.2 & 38.0 & 46.6 & 43.0 & 6.2 & 0.5 \\
\hline Sp $\dagger$ & 40 & 35 & 146 & 135 & $\begin{array}{l}4.1- \\
6.0\end{array}$ & $\begin{array}{l}4.6- \\
8.8\end{array}$ & 52 & 68 & 8.9 & 13.1 & 17.2 & 19.3 & 3.5 & 0.4 \\
\hline $\mathrm{C}$ & 69 & 55 & 142 & 132 & $\begin{array}{l}4.6- \\
7.0\end{array}$ & $\begin{array}{l}5.6- \\
6.7\end{array}$ & 124 & 90 & 68.0 & 45.9 & 54.8 & 51.0 & 15.9 & 0.4 \\
\hline B & 63 & 34 & 145 & 124 & $\begin{array}{l}3.7- \\
5.2\end{array}$ & $\begin{array}{l}4.6- \\
8.0\end{array}$ & 103 & 75 & 58.5 & 41.6 & 57.0 & 55.5 & 35.2 & 1.7 \\
\hline $\mathbf{M}$ & 72 & 46 & 146 & 119 & $\begin{array}{l}4.5- \\
5.8\end{array}$ & $\begin{array}{l}5.7- \\
6.1\end{array}$ & 88 & 48 & 32.0 & 33.5 & 36.8 & 70.0 & 9.7 & 0.5 \\
\hline W & 33 & 40 & 145 & 136 & $\begin{array}{l}3.9- \\
7.0\end{array}$ & $\begin{array}{l}4.7- \\
7.7\end{array}$ & 81 & $91^{\circ}$ & 25.0 & 52.5 & 30.9 & 57.5 & 10.7 & 3.5 \\
\hline $\mathrm{S} \dagger$ & 45 & 29 & 148 & 136 & $\begin{array}{l}4.4- \\
7.2\end{array}$ & $\begin{array}{l}4.3- \\
8.1\end{array}$ & 100 & 107 & 58.5 & 44.5 & 58.5 & 41.5 & 30.1 & 1.3 \\
\hline
\end{tabular}

* The experimental protocol described (see Methods) was followed for each clearance study. $\mathrm{KCl}$ infusions were administered to Dogs $\mathrm{P}, \mathrm{T}, \mathrm{G}, \mathrm{Sp}$ and $\mathrm{C}$. The others received $\mathrm{K}_{2} \mathrm{SO}_{4}$. The plasma sodium concentrations recorded are those from blood drawn before the infusions were started. The range of plasma potassium concentrations from the beginning of each study to the end of the potassium infusion is shown. The total amount of potassium administered, the total amount of potassium excreted, and the total amount of sodium excreted during the potassium infusions are recorded.

$\dagger$ Died at conclusion of clearance study following $\mathrm{Na}$ depletion.

$\ddagger \mathrm{B}$, before $\mathrm{NaCl}$ depletion; $\mathrm{A}$, after $\mathrm{NaCl}$ depletion. 
TABLE II

Sodium, potassium and chloride excretion during potassium chloride infusion

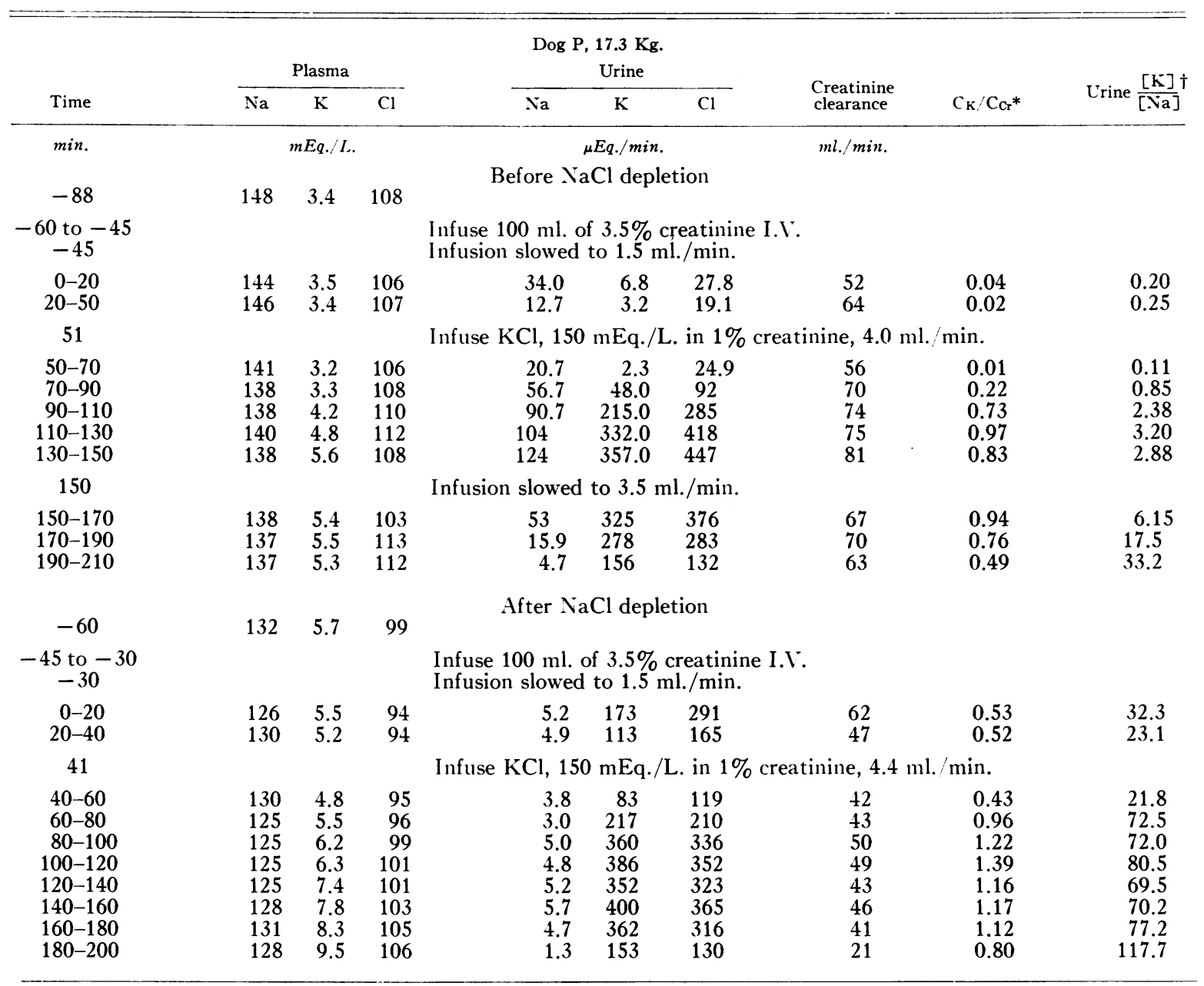

${ }^{*} \mathrm{C}_{\mathrm{K}}$, clearance of $\mathrm{K}, \mathrm{ml} . / \mathrm{min}$.; $\mathrm{C}_{\mathrm{C}_{\mathrm{r}}}$, clearance of creatinine, ml./min.; $\mathrm{C}_{\mathrm{K}} / \mathrm{C}_{\mathrm{C}_{r}}$, excreted $\mathrm{K} /$ filtered $\mathrm{K}$.

$\dagger[]=$ concentration.

ployed (9). Sodium depletion produced a marked decrease in the amount of sodium in the urine, but large amounts of potassium again appeared in the urine during the clearance study despite a reduced dose of $\mathrm{K}_{2} \mathrm{SO}_{4}$. The $\mathrm{C}_{\mathrm{K}} / \mathrm{C}_{\mathrm{Cr}}$ ratios were actually higher after sodium depletion in this animal.

Three studies were accomplished in Dog W (Table IV). The first two were the standard control and postdialysis studies. The third was done following surgical constriction of the thoracic vena cava and the development, subsequently, of ascites. After operation and for six weeks before the clearance study, the 24 hour urine sodium from this animal was less than $2 \mathrm{mEq}$. per day. Potassium excretion appeared equally efficient in the control, in the sodium depleted, and in the sodium retaining states.

Figure 1 is a graphic representation of the amount of potassium excreted per minute during each 20 minute clearance period in the 18 clearance studies. The data in the left of Figure 1 were taken from experiments done in normal animals and those in the right side of the figure from the same animals following sodium depletion. The distribution of points in the two graphs is similar. The plasma potassium concentrations during the infusions have been averaged for each period and are also illustrated. In the studies done after sodium depletion the plasma potassium levels were higher than in the control studies. 
TABLE III

Sodium and potassium excretion during potassium sulfate infusion

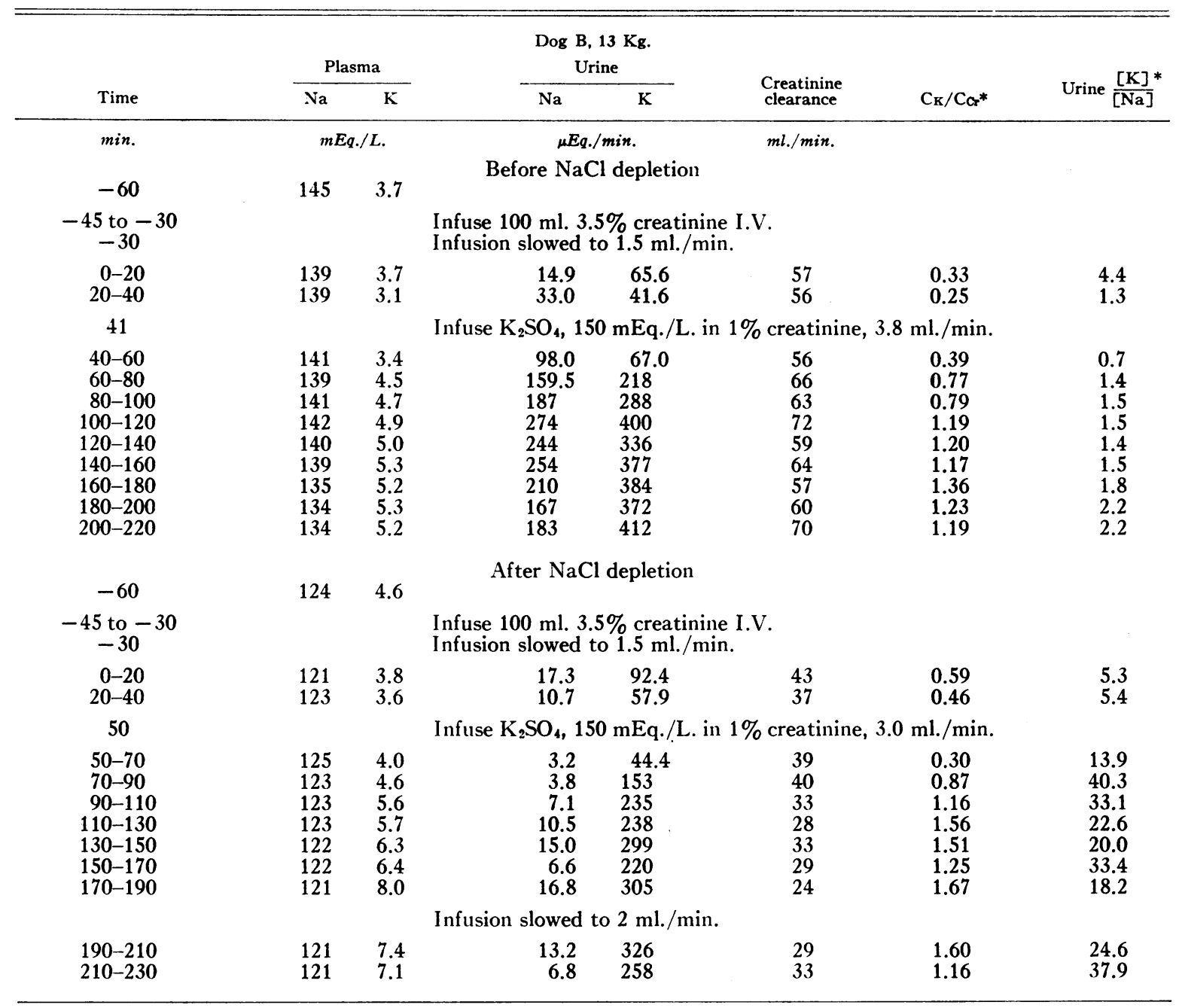

* See Table II for meaning of these abbreviations.

In Figure 2 the cumulative excretion of potassium before and after sodium depletion is related to the concurrent cumulative excretion of sodium. It can be seen that the excretion of potassium remained high despite a marked reduction in urinary sodium and a diminution in glomerular filtration rate.

Figure 3 illustrates two examples of the hyperkalemia usually observed in the sodium depleted animal. The plasma potassium concentration has been correlated with the cumulative positive potassium balance. It is again evident that the higher plasma potassium concentration in the sodium depleted animal cannot be attributed to a difference in the amount excreted. Not only was the initial plasma potassium concentration of the sodium depleted dogs uniformly higher than that of the normal animals ( $c f .$, Table I) but the difference in concentration was exaggerated as the potassium salts were infused. In each dog identical degrees of potassium retention were observed before and after sodium depletion despite marked differences in the levels of plasma potassium.

\section{DISCUSSION}

The experiments reported here demonstrate that the renal excretion of infused potassium salt may 
TABLE IV

Sodium and potassium excretion during potassium sulfate infusion

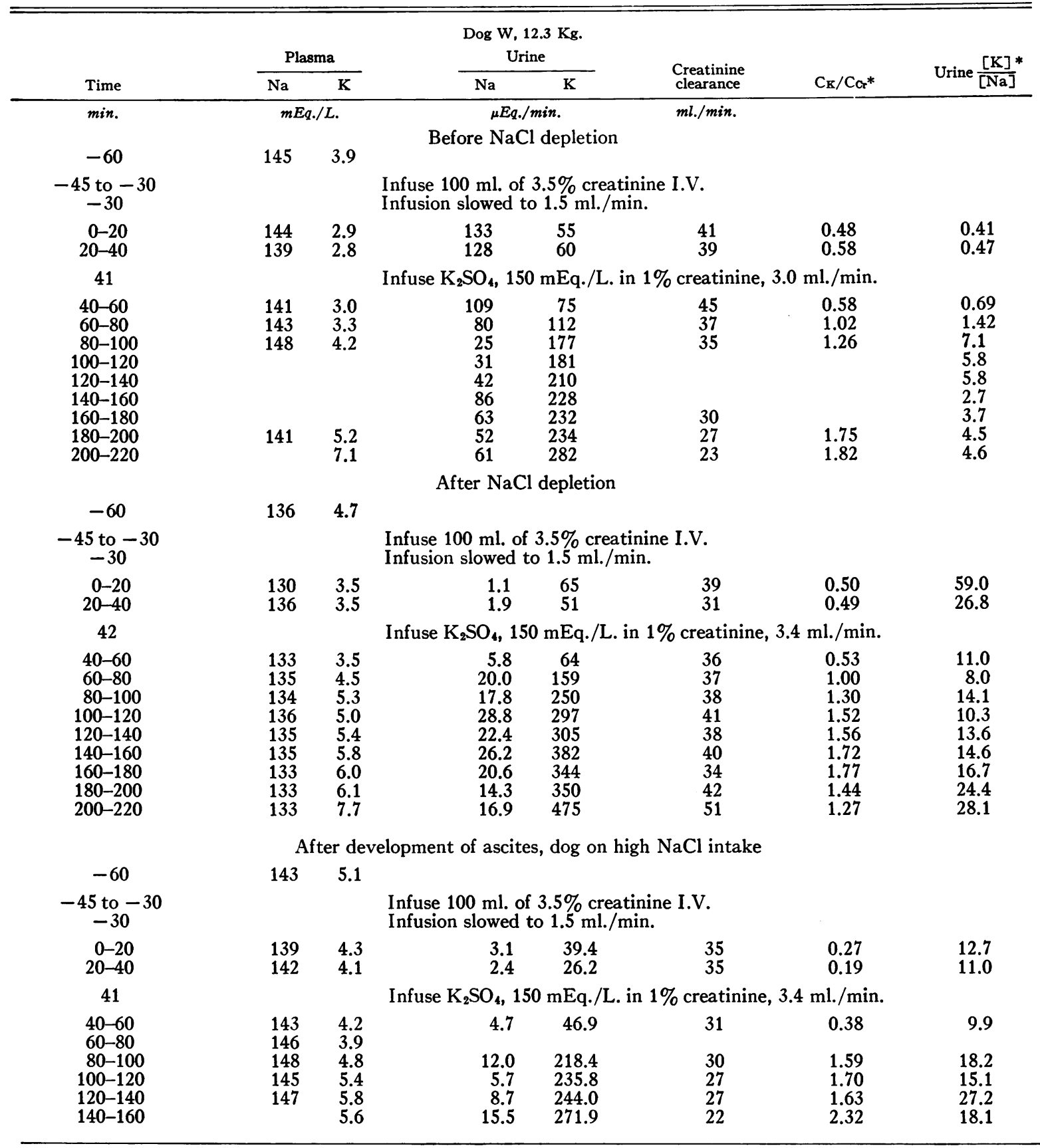

* See Table II for meaning of these abbreviations.

not be demonstrably impaired by the imposition of a rather severe state of sodium chloride depletion. This depletion was characterized by a significant reduction in plasma sodium concentration, and frequently by a reduced glomerular filtration rate. There was, consequently, a considerable reduction in the filtered load of sodium, and the sodium concentration of the urine was extremely low. The degree of sodium depletion thus accomplished was, in general, greater than that ob- 

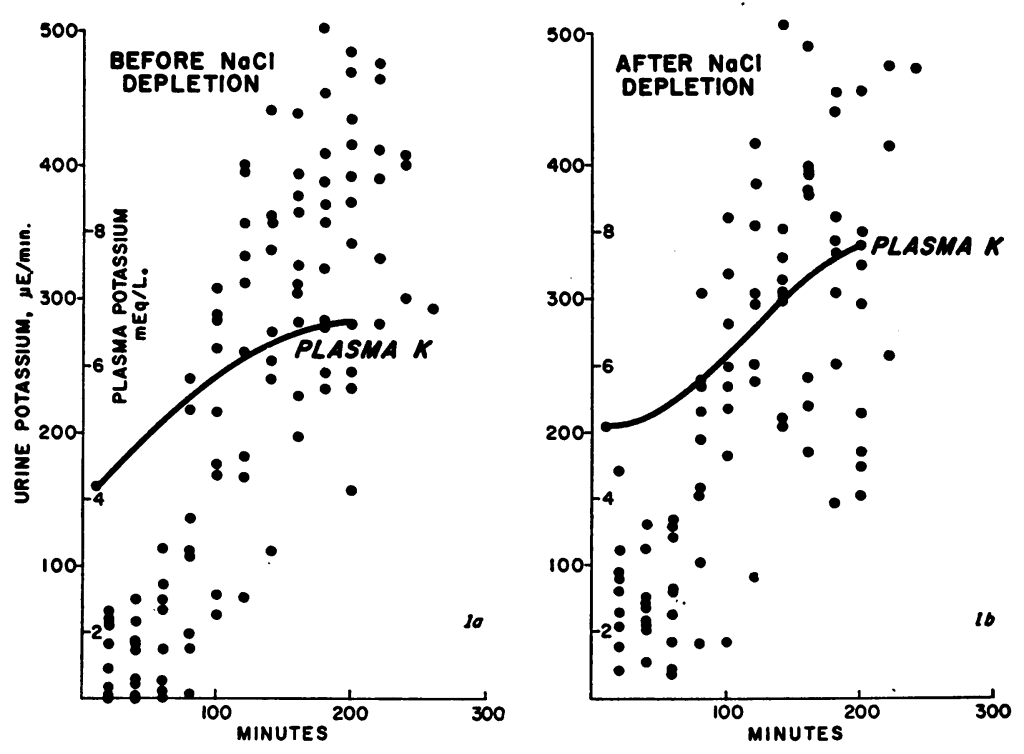

Fig. 1. Potassium Excretion During Each Clearance Period for Nine Dogs Before and After Sodium Depletion

The average plasma potassium concentration is represented by the heavy line. In the studies done in normal dogs the average rate of infusion of potassium was $537 \mu$ Eq. per minute; in studies in sodium depleted animals it was $531 \mu$ Eq. per minute.

served in patients. Therefore, it may be worthwhile to reappraise the hypothesis that potassium secretion is impaired in those situations in which the sodium content of urine in the distal tubule is reduced.

Demonstration of potassium secretion (as evidenced by a $C_{K} / C_{C r}$ ratio greater than one) was facilitated by the reduction in GFR usually seen in sodium depleted dogs. Not only was secretion demonstrated, but the depleted animals were capable of excreting a fraction of the administered potassium which was equal to or greater than that in the control experiment. Moreover, there is considerable evidence that in the normal animal nearly all urinary potassium is secreted (5). The means by which an acute potassium load is excreted by the kidney of the salt depleted animal has not been fully elucidated. At least four possible explanations may be presented:

1. A large portion of the acute potassium load may be filtered and excreted without reabsorption. Such an assumption implies the abrupt development of faulty reabsorption. It is clear from the chronic experiment (7) and the data in the control periods before potassium infusion that considerable reabsorption of potassium does occur. However, the possibility remains that the

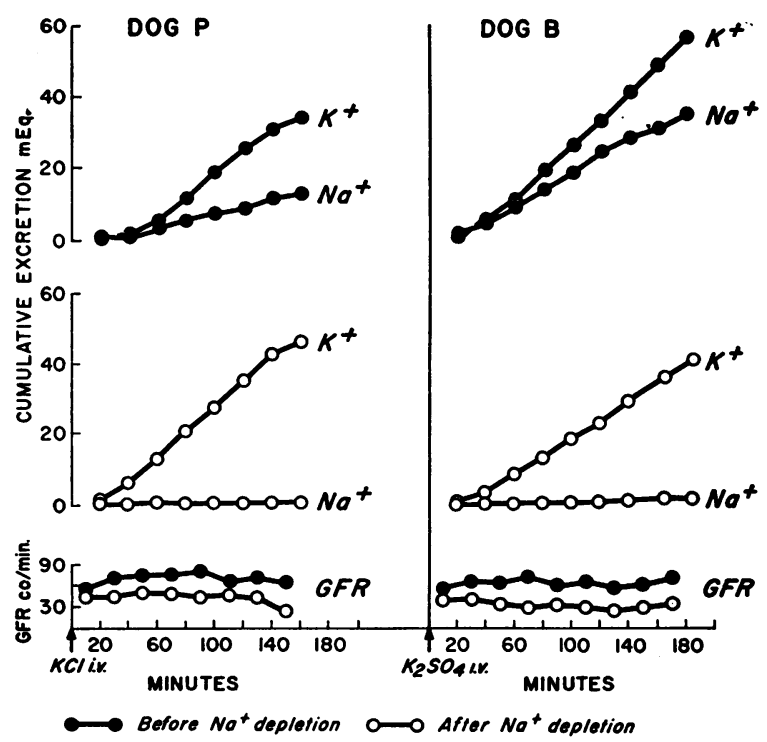

Fig. 2. Cumulative Potassium Excretion After SoDIUM DEPLETION

Results are similar to the control study, although urine sodium is markedly reduced and the glomerular filtration rate is lower. 


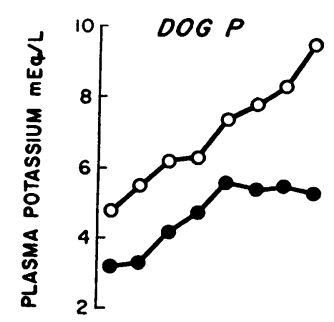

DOG B

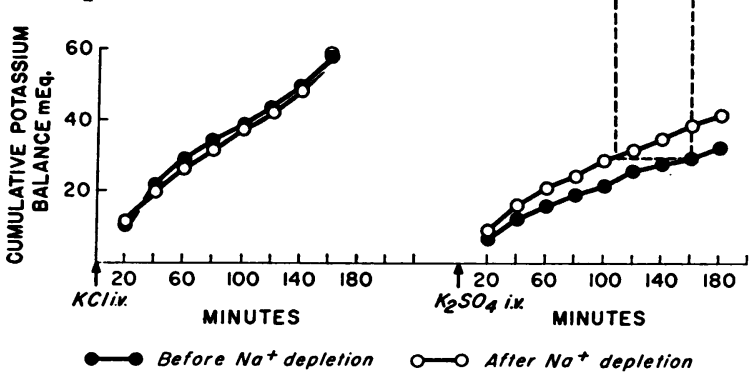

Fig. 3. Relationship of Plasma Potassium to the Cumulative Potassium Balance During Potassium Infusions Before and After Sodium Chloride DePLETION

After depletion there is a considerable hyperkalemia at a time when the cumulative potassium balance is similar to the control. The dotted lines indicate the differences in plasma potassium in the normal and sodium depleted states at comparable degrees of positive potassium balance.

reabsorptive capacity is limited and that this limit has been exceeded by the load.

2. It is also possible that some fraction of the administered potassium is secreted by the tubule with an anion. Present data cannot exclude this.

3. Proximal sodium reabsorption may be reduced when a large load of potassium chloride or sulfate is given. This would increase the amount of sodium available in the distal tubule for ion exchange with potassium. The slight increase in final urine sodium usually observed during potassium infusion could be interpreted as support for the suggestion that there was a change in proximal sodium reabsorption. If proximal reabsorption were constant one might expect a decrease in urine sodium excretion as potassium excretion increases.

4. Presently available evidence (10) suggests that approximately one-eighth of the filtered load of sodium would be available for potassium exchange in the distal tubular urine. If this concept is applied to states of sodium depletion there would be an adequate amount of sodium in the distal tubule even under the most severe conditions of sodium depletion. The experiments reported here do not exclude the possibility that potassium excretion has been accomplished by means of exchange of potassium ions from the tubule cell for sodium ions in the urine of the tubule. Indeed, the ion exchange mechanism may be operating maximally with the result that only a small amount of sodium escapes into the final urine.

The demonstration, under the conditions of the present study, that potassium excretion is not limited by sodium depletion, appears to be an unexpected observation in the light of the hypothesis advanced by Berliner (5) and Howell and Davis (4). These workers postulated that, if the amount of sodium available in the distal tubule is reduced either by a low sodium diet or the production of a sodium retaining state, potassium secretion by ion exchange for sodium is curtailed. Examples of the many instances which support this hypothesis have already been cited. However, in view of the findings reported here, factors (in addition to the available sodium) which might be concerned with the regulation of potassium secretion must be considered. The interrelationship of potassium and hydrogen is well known, and a competition between these two ions for renal secretion has been proposed (11). In the previously described situations in which limitation of potassium excretion was associated with sodium deprivation, there has been a tendency toward extracellular alkalosis. In extracellular alkalosis, an increased hydrogen ion concentration of renal tubular cells has been found (12). This probably favors $\mathrm{Na}-\mathrm{H}$ exchange when the filtered load of sodium is low. When more sodium is available, greater stress may be applied to the mechanism and potassium secretion occurs by means of $\mathrm{Na}-\mathrm{K}$ exchange. Operation of this competitive mechanism may be important in the potentiation of potassium excretion when there is abundant sodium in the distal tubule.

In contrast, animals receiving potassium chloride or sulfate infusions exhibit extracellular acidosis (9). The present data indicate that in both the normal and sodium depleted dogs a large amount of the infused potassium enters cells. The extracellular acidosis may be the result of the exchange of administered potassium for intracellular hydrogen and a corresponding intracellular alkalosis may result. One might postulate that in 
the normal and the sodium depleted animals in the study reported here, a decrease in intracellular hydrogen and an increase in intracellular potassium favor secretion of this latter ion. A quantification of acid-base balance under the conditions of these experiments may be useful.

In the present study significant hyperkalemia was observed in all of the sodium depleted dogs during the infusion of potassium. The elevations of plasma potassium could not be accounted for by failure of renal excretion. Approximately 40 per cent of the administered dose appeared in the urine during these experiments. The remainder was stored temporarily outside the extracellular fluid, presumably within cells. The data suggest that the hyperkalemia of sodium depletion might be related to a change in the capacity to transfer additional potassium into cells. Sodium depletion may alter membrane transport of potassium or may actually lead to a change in intracellular environment which limits further storage. Yannet and Darrow (13) have found increased intracellular potassium in cats depleted of sodium chloride by peritoneal dialysis. This increase may be the cause of the reduction in the capacity for additional cellular uptake.

The study emphasizes again the hazards of potassium administration when there is sodium depletion. Following potassium infusions to sodium depleted animals, arrhythmias and electrocardiographic changes were frequently observed. Four of the nine animals reported here $(P, G, S p$ and $\mathrm{S})$ died after the experiment. The net positive potassium balance in these animals was no greater following sodium depletion than in the control study, but at the conclusion of the potassium infusions (after $\mathrm{Na}$ depletion), the plasma potassium concentrations were all above $8 \mathrm{mEq}$. per $\mathrm{L}$. In the sodium depleted state the cardiac toxicity appears to be directly related to the concentration of potassium in the extracellular fluid.

\section{SUMMARY}

The effect of sodium depletion on plasma potassium concentration and on the capacity of the kidney to excrete potassium has been examined.

The renal excretion of potassium in sodium depleted dogs was quantitatively similar to that of the control animal. Renal tubular secretion of potassium was demonstrated in severe sodium depletion, and reduction of available sodium could not be made a limiting factor for potassium excretion.

The data suggest that the available sodium in the distal tubule is not the sole factor governing potassium excretion in sodium retaining states. It has been proposed that a change in intracellular $\mathrm{pH}$ may be important in regulating potassium secretion under these circumstances.

After sodium depletion animals exhibited hyperkalemia which could not be attributed to failure of renal excretion of infused potassium.

The cardiac toxicity of potassium in states of sodium depletion was again demonstrated and appeared to be related to an increased extracellular potassium concentration.

\section{ACKNOWLEDGMENT}

The authors wish to thank Dr. John V. Taggart for help, advice and encouragement throughout the course of these studies.

\section{REFERENCES}

1. Seldin, D. W., Welt, L. G., and Cort, J. The effect of pituitary and adrenal hormones on the metabolism and excretion of potassium (abstract). J. clin. Invest. 1951, 30, 673.

2. Relman, A. S., and Schwartz, W. B. The effect of DOCA on electrolyte balance in normal man and its relation to sodium chloride intake. Yale $\mathrm{J}$. Biol. Med. 1952, 24, 540.

3. Milne, M. D., Hughes Jones, N. C., and Evans, B. M. Electrolyte excretion in states of potassium depletion in man in Ciba Foundation Symposium on the Kidney. Boston, Little Brown \& Co., 1954, p. 212.

4. Howell, D. S., and Davis, J. O. Relationship of sodium retention to potassium excretion by the kidney during administration of desoxycorticosterone acetate to dogs. Amer. J. Physiol. 1954, 179, 359.

5. Berliner, R. W. The kidney. Ann. Rev. Physiol. 1954, 16, 269.

6. Laragh, J. H. The effect of potassium chloride on hyponatremia. J. clin. Invest. 1954, 33, 807.

7. Laragh, J. H., and Capeci, N. E. Effect of administration of potassium chloride on serum sodium and potassium concentration. Amer. J. Physiol. 1955, 180, 539.

8. Darrow, D. C., and Yannet, H. The changes in the distribution of body water accompanying increase and decrease in extracellular electrolyte. J. clin. Invest. 1935, 14, 266. 
9. Berliner, R. W., Kennedy, T. J., Jr., and Hilton, J. G. Renal mechanisms for excretion of potassium. Amer. J. Physiol. 1950, 162, 348.

10. Smith, H. W. The Kidney: Structure and Function in Health and Disease. New York, Oxford University Press, 1951.

11. Berliner, R. W., Kennedy, T. J., Jr., and Orloff, J. Relationship between acidification of the urine and potassium metabolism. Amer. J. Med. 1951, 11, 274.

12. Anderson, H. M., and Mudge, G. H. The effect of potassium on intracellular bicarbonate in slices of kidney cortex. J. clin. Invest. 1955, 34, 1691.

13. Yannet, H., and Darrow, D. C. The effect of depletion of extracellular electrolytes on the chemical composition of skeletal muscle, liver, and cardiac muscle. J. biol. Chem. 1940, 134, 721.

\section{ANNOUNCEMENTS OF MEETINGS}

The Fiftieth Annual Meeting of THE AMERICAN SOCIETY FOR CLINICAL INVESTIGATION will be held in Atlantic City, N. J., on Monday, May 5, 1958, at 9:00 A.M. at the Casino Theater on the Steel Pier.

The Fifteenth Annual Meeting of THE AMERICAN FEDERATION FOR CLINICAL RESEARCH will be held in Atlantic City, N. J., at the Casino Theater on the Steel Pier on Sunday, May 4, 1958, at 9:00 A.M.

THE ASSOCIATION OF AMERICAN PHYSICIANS will hold their Seventy-First Annual Meeting in Atlantic City, N. J., at the Casino Theater on the Steel Pier on Tuesday, May 6, 1958, at 9:30 A.M. and in the Vernon Room, Chalfonte-Haddon Hall on Wednesday, May 7, 1958, at 9:30 A.M.

\section{SPECIAL NOTICE TO SUBSCRIBERS}

Post Offices will no longer forward the Journal when you move.

Please notify The Journal of Clinical Investigation, Business Office, 333 Cedar Street, New Haven 11, Conn., at once when you have a change of address, and do not omit the zone number if there is one. 